\title{
AquaCrop parametrisation for quinoa in arid environments
}

\author{
Jorge Alvar-Beltrán, ${ }^{1}$ Anne Gobin, ${ }^{2,3}$ Simone Orlandini, ${ }^{1}$ Anna Dalla Marta ${ }^{1}$ \\ ${ }^{1}$ Department of Agriculture, Food, Environment and Forestry (DAGRI), University of Florence, Italy; \\ ${ }^{2}$ Flemish Institute for Technological Research (VITO), Mol, Belgium; ${ }^{3}$ Department of Earth and \\ Environmental Sciences, Faculty of BioScience Engineering, University of Leuven, Belgium
}

\begin{abstract}
Highlights
- $\quad 13 \%$ yield losses when comparing progressive drought with full irrigated treatments.

- $25 \%$ water savings when comparing progressive drought with full irrigated treatments.

- Calibrated and validated NRMSE values of $10.0 \%$ and $13.3 \%$ for biomass, respectively.

- Calibrated and validated NRMSE values of $19.2 \%$ and $7.3 \%$ for yield, respectively.
\end{abstract}

\begin{abstract}
The resilience of quinoa to drought stress conditions makes the crop suitable for the Sahel region. It can support grain production during the dry season and be considered an alternative crop for alleviating food insecurity within the region. Given the importance of this crop outside the indigenous cultivation area, there is a requisite for the development of crop models to facilitate further expansion of quinoa along the Sahel region. Crop water models are of interest due to increasing pressure on water resources, and the portrayal of irrigation scheduling as the best option for water optimisation. The AquaCrop model was selected, as this model simulates crop development and derives both optimal frequencies
\end{abstract}

Correspondence: Jorge Alvar-Beltrán, Department of Agriculture, Food, Environment and Forestry (DAGRI), University of Florence, Piazzale delle Cascine 18, 50144 Florence, Italy.

E-mail: jorge.alvar@unifi.it

Key words: Water management; calibration; validation; climate resilient crops; Sahel region.

Acknowledgements: Special recognitions to the Institut de l'Environnement et de Recherches Agricoles (INERA) for providing this research with an experimental field between 2017 and 2019, as well as to the Food and Agriculture Organisation of the United Nations (FAO) for the provision of quinoa seeds.

Received for publication: 5 October 2020.

Revision received: 28 November 2020.

Accepted for publication: 11 December 2020.

(C) Copyright: the Author(s), 2021

Licensee PAGEPress, Italy

Italian Journal of Agronomy 2021; 16:1749

doi:10.4081/ija.2020.1749

This article is distributed under the terms of the Creative Commons Attribution Noncommercial License (by-nc 4.0) which permits any noncommercial use, distribution, and reproduction in any medium, provided the original author(s) and source are credited. and net applications of irrigation. Due to limited water resources in the region, different irrigation regimes [full irrigation, progressive drought (PD), deficit irrigation and extreme deficit irrigation] were proposed for analysing yield and biomass responses to water stress conditions. Results suggest that yields were stabilised at around $1.0 \mathrm{Mg} \mathrm{ha}^{-1}$ under $\mathrm{PD}$, thereby prioritising maximum water productivity rather than maximum yields. Water optimisation was attained by watering less at a suggested $310 \mathrm{~mm}$, but with more frequent irrigation events, 28 rather than 20.

\section{Introduction}

Africa is considered as the world's most vulnerable continent to climate change due to a low adaptive capacity (Niang et al., 2014). The Sahel region, consisting of countries within the southernmost parts of the Sahara Desert, is considered a hotspot of climate change, with unprecedented future climate (Mora et al., 2013). Future trends for precipitation over West Africa show an inter-annual variability increase of up to $40 \%$ by the end of the century (Yabi and Afouda, 2012; Niang et al., 2014). Specifically, for Burkina Faso, regional climate models estimate a significant precipitation decline over the 2021-2050 period (Ibrahim et al., 2014). Changes in the onset/offset of the rainy season are also being observed. Emphasis on the impact of onset delay has been shown, thereby shortening the growing season of rainfed crops (Biasutti and Sobel, 2009; Alvar-Beltrán et al., 2020a).

Traditional water harvesting practices (zaï, half-moons and stone bunds, among others) are widely used in Burkina Faso to cope with the high rainfall variability (Barbier et al., 2009; Sawadogo et al., 2008). Nonetheless, these techniques are inefficient for coping with changing precipitation patterns. Moreover, only $0.9 \%$ of the surface area for cultivation in the country is irrigated, with most of the area based on surface irrigation systems (FAO, 2011). Furthermore, both the proliferation of and lack of imposed authority on uncontrolled pumping, particularly from small reservoirs and groundwater, are exacerbating the pressure on water resources (de Fraiture, 2014). For this reason, appropriate water management strategies are vital for stabilising crop yields, besides sustaining increasing water demands.

Very few modelling studies, using Hydrus and Cropwat programs, are available with different irrigation regimes and crops for 
Burkina Faso. Mermoud et al. (2005) affirm that for onion in Kamboinse, less frequent-weekly irrigation increases water storage in the root zone in comparison to daily irrigation that leads to higher evaporation rates due to direct soil evaporation. Wang et al. (2009) have estimated the water demand of different rainfed and vegetable crops in Ouagadougou and Banfora, thereby concluding that tailored irrigation regimes are necessary for satisfying crop water demands during critical growing stages. In arid and semiarid environments water used for crop growing has been scarcely examined from a crop modelling perspective. Overall, there is a perquisite to expand our insights by identifying constraints to crop production and water productivity; particularly relevant for arable crops, for which there is not yet documented literature in the Sahel.

The AquaCrop model is a crop water productivity model developed by the Food and Agriculture Organisation (FAO). This model simulates biomass and yield responses to water for multiple crop and different environmental conditions. It allows to optimize water resources in regions where water is a limiting factor for crop production (Raes et al., 2009; Steduto et al., 2009; FAO, 2019). Scant use of the AquaCrop model has been made in Sub-Saharan Africa, with most of the research focusing on the modelling of vegetable crops (Karunaratne et al., 2011; Sam-Amoah et al., 2013; Darko et al., 2016). Some validations of the model have been conducted on arable crops, e.g. in Nigeria with different levels of nitrogen fertilisation for rainfed maize, as well as in Ethiopia testing deficit irrigation regimes on barley and sorghum (Araya et al., 2010; Araya et al., 2016; Akumaga et al., 2017). Regarding the crop of interest, quinoa (Chenopodium quinoa Willd.), both calibration and validation of the model have only been performed in the environment of origin, namely, the Bolivian Altiplano (Geerts et al., 2009; Geerts et al., 2010).

Given that the AquaCrop model was used previously on quinoa to estimate acceptable economic losses under deficit irrigation in Bolivia, the objective of the present study was to calibrate and val- idate the AquaCrop model for quinoa under different irrigation regimes during the dry season in Burkina Faso. Additionally, since quinoa is a new crop for the country, optimal irrigation scheduling is crucial for saving farmers expenses, improving yields and preserving water resources. Finally, due to its rapid expansion in new environments facing food insecurity and water related issues, the parametrization of the model's phenological and physiological parameters becomes imperative.

\section{Materials and methods}

\section{Experimental site}

Quinoa yields and biomass were simulated using the AquaCrop model (version 6.0, 2017) for one location, Institut de l'Environnement et de Recherches Agricoles (INERA), Farako-Ba

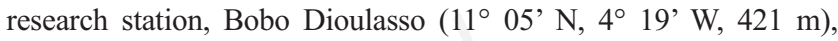
Burkina Faso. The two-year experiments were performed in a typical Soudanian savannah climate, with warm mean temperatures and a well-defined rainy season (May-October). The sowing dates were $25 / 10 / 2018$ and $19 / 11 / 2018$ for the calibration, and 4/11/2017 and $8 / 12 / 2017$ for the validation (Table 1). Four different irrigation regimes were used according to the crop evapotranspiration (Etc) and were determined as follows: i) full irrigation (FI) (the crop was fully supported by applied water, $100 \%$ Etc, throughout the growing cycle); ii) progressive drought (PD) (water was withheld in short amounts throughout the growing cycle and the overall Etc was 70$90 \%$ ); iii) deficit irrigation (DI) (the crop was exposed to a certain level of stress of about $50 \%$ Etc throughout the growing cycle); iv) extreme deficit irrigation (EDI) (the crop was exposed to a very high level of stress, $\leq 40 \%$ Etc, being just above wilting point throughout the growing cycle).

Table 1. Crop evapotranspiration (Etc) for different irrigation regimes: full irrigation (FI), progressive drought (PD), deficit irrigation (DI) and extreme deficit irritation (EDI).

\begin{tabular}{|c|c|c|c|c|c|c|c|c|c|c|}
\hline \multirow{2}{*}{$\begin{array}{l}\text { Experimental year } \\
\text { Irrigation treatment }\end{array}$} & \multicolumn{4}{|c|}{$\begin{array}{c}\text { Calibrated values } \\
\text { 2018-2019 }\end{array}$} & \multicolumn{6}{|c|}{$\begin{array}{l}\text { Validated values } \\
2017-2018\end{array}$} \\
\hline & $\mathrm{T}_{1}$ & $\mathrm{~T}_{2}$ & $\mathrm{~T}_{3}$ & $\mathrm{~T}_{4}$ & $\mathrm{~T}_{5}$ & $\mathrm{~T}_{6}$ & $\mathrm{~T}_{7}$ & $\mathrm{~T}_{8}$ & $\mathrm{~T}_{9}$ & $\mathrm{~T}_{10}$ \\
\hline Sowing date & $25 / 10$ & $25 / 10$ & $19 / 11$ & $19 / 11$ & $4 / 11$ & $4 / 11$ & $4 / 11$ & $8 / 12$ & $8 / 12$ & $8 / 12$ \\
\hline Transplanting date & $12 / 11$ & $12 / 11$ & $7 / 12$ & $7 / 12$ & $22 / 11$ & $22 / 11$ & $22 / 11$ & $26 / 12$ & $26 / 12$ & $26 / 12$ \\
\hline Irrigation regimes & $\mathrm{FI}$ & EDI & FI & DI & PD & PD & DI & PD & DI & EDI \\
\hline Irrigation + Precipitation (mm) & 421 & 154 & 409 & 191 & 350 & 263 & 198 & 310 & 202 & 98 \\
\hline$\sum$ irrigation events & 20 & 22 & 21 & 23 & 30 & 29 & 28 & 20 & 21 & 18 \\
\hline$\sum E t c(\mathrm{~mm})$ & 394 & 394 & 416 & 416 & 387 & 387 & 387 & 388 & 388 & 388 \\
\hline Etc (\%) & 107 & 39 & 98 & 46 & 90 & 70 & 51 & 80 & 52 & 31 \\
\hline Total water savings (\%) & - & 62.9 & - & 54.0 & 15.7 & 34.5 & 52.3 & 25.3 & 51.3 & 76.4 \\
\hline Avg. irrigation (1-3 weeks) (mm) & 13.8 & 7.6 & 19.3 & 5.1 & 7.8 & 6.6 & 5.7 & 18.2 & 7.7 & 6.0 \\
\hline Avg. irrigation (4-7 weeks) (mm) & 28.0 & 6.9 & 18.7 & 10.0 & 13.3 & 11.4 & 7.7 & 16.0 & 12.7 & 4.7 \\
\hline Avg. irrigation (8-10 weeks) (mm) & 24.7 & 6.5 & 21.3 & 10.9 & 17.5 & 11.3 & 9.3 & 11.2 & 5.9 & 6.4 \\
\hline Mean T flowering $\left({ }^{\circ} \mathrm{C}\right)$ & 34.6 & 34.6 & 33.2 & 33.2 & 33.5 & 33.5 & 33.5 & 34.8 & 34.8 & 34.8 \\
\hline Max T flowering $\left({ }^{\circ} \mathrm{C}\right)$ & 35.5 & 35.5 & 35.0 & 35.0 & 36.5 & 36.5 & 36.5 & 35.5 & 35.5 & 35.5 \\
\hline$\sum$ Irrigation flowering (mm) & 73.7 & 15.9 & 51.5 & 36.1 & 46.3 & 28.4 & 18.7 & 35.4 & 24.5 & 19.2 \\
\hline$\sum$ Etc flowering (mm) & 63.5 & 63.5 & 61.5 & 61.5 & 49.0 & 49.0 & 49.0 & 53.9 & 53.9 & 53.9 \\
\hline
\end{tabular}

Full irrigation (FI) was applied in treatments 1 and 3 , progressive drought (PD) in treatments 5, 6 and 8 , deficit irrigation (DI) in treatments 4, 7 and 9 , and extreme deficit irrigation (EDI) in treatments 2 and 10 . The crop evapotranspiration (Etc) was calculated by dividing the sum of observed irrigation and precipitation by the accumulated crop evapotranspiration (Etc) simulated in AquaCrop as a percentage. Finally, the total water savings were calculated as the difference between the average of full irrigation treatments $\left(\mathrm{T}_{1}\right.$ and $\left.\mathrm{T}_{3}\right)$ and the rest of the irrigation regimes $\left(\mathrm{T}_{2}, \mathrm{~T}_{4}, \mathrm{~T}_{5}, \mathrm{~T}_{6}, \mathrm{~T}_{7}, \mathrm{~T}_{8}, \mathrm{~T}_{9}\right.$, and $\left.\mathrm{T}_{10}\right)$. 
While the number of treatments (T) used for the calibration was four $\left(\mathrm{T}_{1-4}\right)$, for the validation was six $\left(\mathrm{T}_{5-10}\right)$. Overall, the number of treatments were substantiate to draw robust conclusions for both the calibration and validation. In addition, to verify that the selected sowing dates did not have an impact on yields and biomass, and on the crop-water needs, a set of simulations were conducted with net irrigation requirements (defined as the total amount of irrigation water required to keep the water content in the soil profile above an specific threshold). In that way, AquaCrop estimated the amount of net irrigation necessary to avoid any type of water stress throughout the growing cycle, such that water was not a limiting factor in terms of biomass and yield for achieving the potential crop production.

The experimental field used for the calibration (2018-2019) of the AquaCrop model was set-up in a block-design with three irrigation regimes (FI, DI, EDI, corresponding to treatments $T_{1}$ to $T_{4}$ ) each having eight replicates (refer to Table 1 of the manuscript). The validation (2017-2018) was similarly made up of three irrigation regimes (PD, DI and EDI, corresponding to treatments $\mathrm{T}_{5}$ to $\mathrm{T}_{10}$ ) but, unlike calibration, each treatment was replicated nine times (refer to Table 1 of the manuscript). The plot sized $12.5 \mathrm{~m}^{2}$ (2.5 m width $\times$ $5.0 \mathrm{~m}$ length) for the calibration and $7.5 \mathrm{~m}^{2}(3.0 \mathrm{~m}$ width $\times 2.5 \mathrm{~m}$ length) for the validation. The distance between rows was $50 \mathrm{~cm}$ with plants spacing $10 \mathrm{~cm}$ from each other. The selected quinoa variety was cv. Titicaca, characterised by a short growing cycle (approximately 90 days). As transplanting took place 18 days after sowingDAS, simulations with AquaCrop started on the following dates: $12 / 11 / 2018$ (for the $25 / 10 / 2018$ sowing), 22/11/2017 (for the $4 / 11 / 2017$ sowing), $7 / 12 / 2018$ (for the $19 / 11 / 2018$ sowing) and 26/12/2017 (for the $8 / 12 / 2017$ sowing).

\section{Agronomic practices and irrigation scheduling}

The soil was amended with grassland compost $(50.2 \%$ organic matter) at a rate of $5000 \mathrm{~kg} \mathrm{ha}^{-1}$ and mixed with Burkina phosphate rock - BPR (26.8\% phosphoric anhydride- $\left.\mathrm{P}_{2} \mathrm{O}_{5}\right)$ at a rate of $400 \mathrm{~kg}$ $\mathrm{ha}^{-1}$ and broadcasted a week before sowing. The amount of irrigation was calculated using a water counter placed $(\varnothing 1 / 2 ")$ at the entry of each irrigation block. The timing of irrigation was carried out at post meridiem to avoid losses from direct evaporation, and at a frequency of two to three irrigation events per week depending on the phenological phase and irrigation regime. The drip irrigation system (streamline $\varnothing 16 \mathrm{~mm}$ ) had a flow rate of $1.05 \mathrm{~L} \mathrm{~h}^{-1}$ per emitter and were spaced $30 \mathrm{~cm}$ from each other.

The present study used the Hargreaves and Samani (1985) equation for calculating the daily reference evapotranspiration $\left(\mathrm{ET}_{\mathrm{o}}\right)$ in the field, which required less and more easily available parameters (latitude, maximum, minimum and mean temperatures) than the Penman Monteith equation (crop height, albedo, canopy resistance and evaporation from soil). This choice was based on a cross-comparison of different reference evapotranspiration methods, concluding that the Hargreaves and Samani equation was the most accurate under humid and semi-arid conditions, and concurrently useful in areas with limited climatic data (Tabari et al., 2013; Kra, 2014).

Additionally, to better define the irrigation regimes in the field and to calculate the crop evapotranspiration (Etc), both precipitation and evaporation (using an evaporation pan) measurements were conducted on daily basis. The crop evapotranspiration (Etc) was determined by multiplying the crop coefficient $(\mathrm{Kc})$ by the reference evapotranspiration $\left(\mathrm{ET}_{\mathrm{o}}\right)$ at a given phenological phase, as follows: 0.52 at emergence, 1.00 at maximum canopy cover and 0.70 at physiological maturity (Garcia et al., 2003). The latter Kc values were more suitable, in terms of latitude and energy exchange, for the present study than those recorded by Razzaghi et al. (2012) in Denmark (Kc $0.20,1.20$ and 0.40 for initial, mid and late stages).

\section{Sampling and measurements}

The heat units used for the calibration of the AquaCrop model were, growing degree-days (GDD) and calendar days (DAT). To describe crop development, the following parameters were monitored: time to emergence, flowering, duration of flowering, senescence and maturity (using 100 samples per plot), grain yield per plant (using 12 samples per replicate), dry biomass at 24, 40 and 60 days after sowing-DAS (using 3 samples per replicate and dried at $60^{\circ} \mathrm{C}$ for $48 \mathrm{~h}$ ), canopy cover at $24,34,40,49,70$ and 85 DAS (using 10 samples per replicate), and root depth at harvest (using 1 sample per replicate). The canopy cover was calculated using the Canopeo App. developed by the Oklahoma University in 2015 (Patrignani and Ochsner, 2015). Canopeo readings were made at a $60 \mathrm{~cm}$ distance from the top of the canopy, where each image had a $75 \times 50 \mathrm{~cm}$ coverage. Six soil samples were collected at a depth of $0-20 \mathrm{~cm}$ and $20-40 \mathrm{~cm}$ to determine the physical and chemical characteristics of the soil (Table 2).

\section{AquaCrop model}

The AquaCrop model simulates crop yield in different steps: crop development, crop transpiration, biomass production and yield formation. Instead of the LAI, AquaCrop uses the canopy cover (CC), the fraction of soil surface covered by the green canopy, for describing leaf development. Evapotranspiration is divided into transpiration and soil evaporation. Transpiration is directly related to the $\mathrm{CC}$, while evaporation is proportional to the soil surface not covered by vegetation. In AquaCrop, the CC is multiplied by the reference evapotranspiration $\left(\mathrm{ET}_{\mathrm{o}}\right)$ which is determined by the FAO PenmanMonteith equation and by the crop coefficient $(\mathrm{Kc})$ to then calculate the potential crop transpiration. Then, the actual transpiration (Ta) is calculated from potential evapotranspiration. In addition, the Ta is used for calculating crop biomass (B), which is computed by multiplying actual transpiration by the water productivity (WP) (Eq. 1). Finally, the harvest index (HI) allows to obtain the crop yield (Y) by the crop biomass (B) (Eq. 2) (Raes et al., 2018a).

Crop biomass $(\mathrm{B})=\sum T a * W P$

Crop yield $(\mathrm{Y})=H I * B$

\section{Statistical analysis}

Different statistical indices were used to evaluate the perfor-

Table 2. Soil physic-chemical characteristics.

\begin{tabular}{lccc}
\hline Parameter & Units & \multicolumn{2}{c}{ Soil layer (cm) } \\
& & $0-20$ & $20-40$ \\
Sand & $\%$ & 75.3 & 59.4 \\
Silt & $\%$ & 14.8 & 12.8 \\
\hline Clay & $\%$ & 9.9 & 27.8 \\
Texture (USDA) & & Loamy Sand & Sandy Clay Loam \\
\hline $\mathrm{pH}\left(\mathrm{H}_{2} \mathrm{O}\right)$ & & 6.09 & 5.87 \\
$\mathrm{C}$ & $\%$ & 0.35 & 0.30 \\
\hline Organic matter & $\%$ & 0.60 & 0.51 \\
$\mathrm{~N}_{\text {total }}$ & $\%$ & 0.036 & 0.028 \\
\hline C/N & & 10 & 11 \\
$\mathrm{P}_{\text {available }}$ & $\mathrm{mg} \mathrm{kg}^{-1}$ & 44.0 & 31.3 \\
\hline $\mathrm{K}_{\text {available }}$ & $\mathrm{mg} \mathrm{kg}^{-1}$ & 90.3 & 115.9 \\
Bulk density & $\mathrm{g} \mathrm{cm}^{-3}$ & 1.61 & - \\
\hline
\end{tabular}


mance of the AquaCrop model. The root mean square error (RMSE, Eq. 3) identified the differences between predicted and observed values (Jacovides and Kontoyiannis, 1995), whereas the normalisedRMSE (NRMSE, Eq. 4) provided further information on the average of the measured data ranges. Mean absolute percentage error (MAPE, Eq. 5) expressed the differences between actual and forecasted values as a percentage. For the NRMSE and MAPE, the model had a very high performance when the differences between observed and simulated values were $5 \%$ or lower. A range from $6 \%$ to $15 \%$ was considered as a good performance, and $16 \%$ to $25 \%$ as a moderate-good performance (Raes et al., 2018b). The Willmott's index of agreement (d, Eq. 6) provided a measure of the agreement of the deviation of modelled and observed values from the observed mean, and where 0 indicated disagreement and 1 perfect agreement between predicted values and observed data (Wilmott, 1984). Pearson's correlation coefficient (r) showed the relationship between different irrigation regimes and different crop parameters (biomass and canopy cover). The coefficient of determination $\left(\mathrm{R}^{2}\right)$ calculated the variance of the dependent variable that was predictable from that of the independent variable, and the level of statistical significance (expressed as $\mathrm{P} \leq 0.05$ ) was used to test the null hypothesis. The statistical package used to run the ANOVA and $\mathrm{R}^{2}$ test was Minitab 19.

$\mathrm{RMSE}=\sqrt{\frac{1}{n} \sum_{i=1}^{n}(O i-P i)^{2}}$
$\mathrm{NRMSE}=\frac{R M S E}{\hat{o}} \times 100$

$\mathrm{MAPE}=\sum_{i=1}^{n} \frac{(O i-P i)^{2}}{(O i)} \times 100$

$$
\mathrm{d}=1-\frac{\sum_{i=1}^{n}(O i-P i)^{2}}{\sum_{i=1}^{n}\left(P_{i}^{\prime}+O_{i}^{\prime}\right)^{2}}
$$

where $O_{i}$ and $P_{i}$ are observed and simulated values, respectively; and $n$ is the number of treatments. The RMSE has the same unit as that of the variable being simulated (e.g., $\mathrm{Mg} \mathrm{ha}^{-1}$ for yield and biomass), whereas the units of NRMSE are in percentage. The closer the value is to zero, the better the model simulation performance. In addition, $O^{\prime}{ }_{i}=\left[\mathrm{O}_{\mathrm{i}}-\widehat{\mathrm{O}}\right]$ and $P^{\prime}{ }_{i}=\left[\mathrm{P}_{\mathrm{i}}-\widehat{\mathrm{P}}\right]$ are the differences between an observed and/or simulated value $\hat{O}$ with $\hat{P}]$ and as the observed and simulated means.

\section{Results}

A set of preliminary simulations were run on AquaCrop with net irrigation requirements $(\approx 360 \mathrm{~mm})$ and $\mathrm{ET}_{\mathrm{o}}(\approx 400 \mathrm{~mm})$ confirming that different sowing dates $(25 / 10 / 2018,04 / 11 / 2017$,
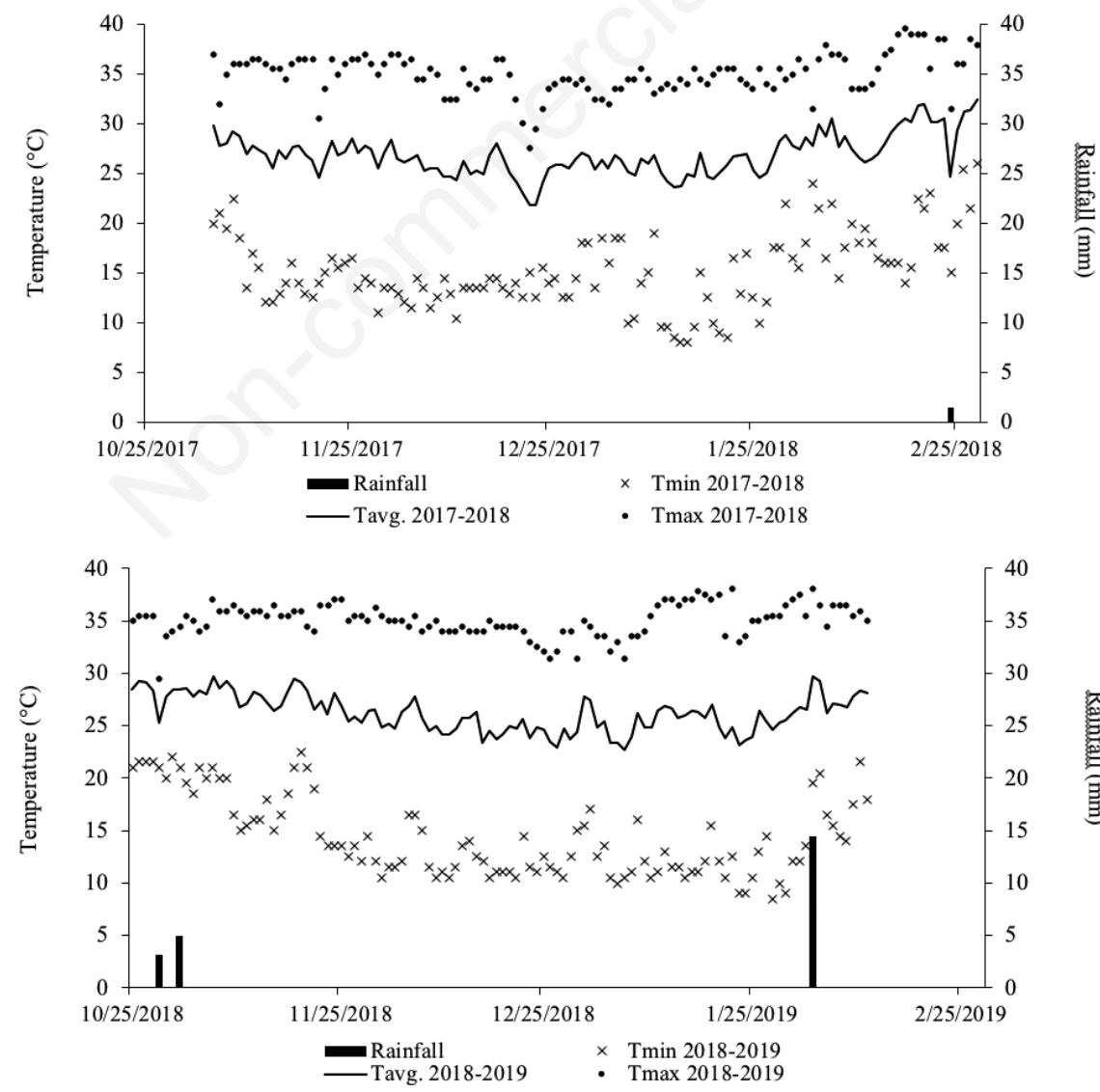

窟

Figure 1. Mean, maximum and minimum temperatures $\left({ }^{\circ} \mathrm{C}\right)$, and precipitation $(\mathrm{mm})$ recorded at Farako-Ba research station during the 2017-2018 (top) and 2018-2019 (bottom) experiments. 
19/11/2018 and 08/12/2017) did not have an impact on the yield (1.05-1.06 $\mathrm{Mg} \mathrm{ha}^{-1} \mathrm{~min} / \mathrm{max}$ value) and biomass (3.00-3.01 Mg $\mathrm{ha}^{-1} \mathrm{~min} / \mathrm{max}$ value). These simulations with net irrigation requirements showed slightly higher biomass and yield values, 14 and 7\% respectively, when compared to field observations under full irrigation. They also demonstrated that accumulated Etc from the field (using Hargreaves and Samani equation) were slightly lower to the Etc calculated by AquaCrop (using Penman Monteith equation). This was probably due to the losses derived from direct evaporation, surface runoff and percolation, which were not accounted for when using the Hargreaves and Samani equation.

\section{Field observations}

The highest accumulated crop evapotranspiration ( $\left.\sum E t c\right)$ was recorded for the sowing date 19/11/2018 (416 $\mathrm{mm} \mathrm{T}_{3}$ and $\mathrm{T}_{4}$ ), largely due to constant high temperatures observed during the vegetative stages of quinoa (Figure 1). Additionally, the quinoa plants sown on the $8 / 12 / 2017$ were adversely affected by heat-stress conditions (above $36^{\circ} \mathrm{C}$ during four consecutive days) occurring at flowering 25 DAT (Figure 2). A positive relationship was observed between the sum of irrigation events (no.) and final yields $\left(\mathrm{r}=0.86\right.$ for the validation treatments, $\mathrm{T}_{5}-\mathrm{T}_{10}$ ), as well as with the amount of irrigation $(\mathrm{mm})$ versus final yields $(\mathrm{r}=0.70$ for the validation treatments, $\mathrm{T}_{5}-\mathrm{T}_{10}$ ), confirming that an appropriate irrigation scheduling was key for obtaining higher yields. Yields were more dependent on the frequency of irrigation $\left(\mathrm{T}_{5-7}\right)$ rather than on its amount $\left(\mathrm{T}_{3}\right)$. For instance, under PD - with a $70-90 \%$ Etc threshold - ( $\mathrm{T}_{5} 350 \mathrm{~mm}$ and $\mathrm{T}_{6} 263 \mathrm{~mm}$ water applied) and DI $\left(\mathrm{T}_{7}, 198 \mathrm{~mm}\right.$ water applied) the number of irrigation events were of 28 to 30 , with yields exceeding, in some cases, $1.0 \mathrm{Mg} \mathrm{ha}^{-1}$ $\left(\mathrm{T}_{6}\right)$. Given that $\mathrm{T}_{5-6}$ and $\mathrm{T}_{7}$ correspond to PD and DI, respectively, surely it was only feasible to compare it to $T_{8}$ and $T_{9}$, representing the same type of treatment but a smaller number of irrigation events (20 to 21 events, respectively). Because of an increase in irrigation events, the yields of $\mathrm{T}_{5}-\mathrm{T}_{7}\left(0.93 \mathrm{Mg} \mathrm{ha}^{-1}\right.$ on average) were considerably higher $(28 \%)$ to those reported by $\mathrm{T}_{8}-\mathrm{T}_{9}$ ( $0.67 \mathrm{Mg} \mathrm{ha}^{-1}$ on average). Despite the fact that EDI treatments were sown in different years (2017 and 2018) and sowing dates (late October and early December), both $\mathrm{T}_{2}$ and $\mathrm{T}_{10}$ showed alike yields ( $\mathrm{T}_{2}: 0.35 \mathrm{Mg} \mathrm{ha}^{-1}$ and $\mathrm{T}_{10}: 0.30 \mathrm{Mg} \mathrm{ha}^{-1}$ ) with similar number of irrigation events $\left(\mathrm{T}_{2}: 22\right.$ and $\left.\mathrm{T}_{10}: 18\right)$. Whereas, $\mathrm{FI}$ treatments $\left(\mathrm{T}_{1}\right.$ and $\left.\mathrm{T}_{3}\right)$, displayed distant yields $\left(0.97\right.$ and $\left.0.73 \mathrm{Mg} \mathrm{ha}^{-1}\right)$ with similar number of irrigation events (20 and 21 events, respectively). Differences in yield between the two were probably due to the timing (specific date during the growing period) of each irrigation event.

\section{Calibration and validation of the AquaCrop model}

The wide genetic variability of quinoa, with thousands of genotypes, made the calibration of AquaCrop more complex. The treatments used for the calibration were $T_{1}$ to $T_{4}$ and for the validation $T_{5}$ to $T_{10}$. The validation was based on a higher number of field experiments, six, as opposed to the calibration, four. In this study, the calibrated parameters on the AquaCrop model were related to climate inputs, crop (development, crop production and response to stresses), management (irrigation and field), soil, and groundwater table. Calibrated values were compared to the AquaCrop's default values for quinoa, displaying significant differences on cycle duration between Burkina Faso and Bolivia (91 DAS and 180 DAS, respectively) (Table 3). In general, the timing and duration of different crop development stages (time and duration of flowering, time for maximum canopy cover and maturity, among other parameters) were halved when comparing the present research to the default values calibrated in Bolivia. High temperatures and short photoperiodicity in Burkina Faso were the principle factors explaining the shortening of the growing period, and consequently of the different phenological phases. For the calibration of air temperature stresses on pollination, the present research adjusted the response of quinoa to heat

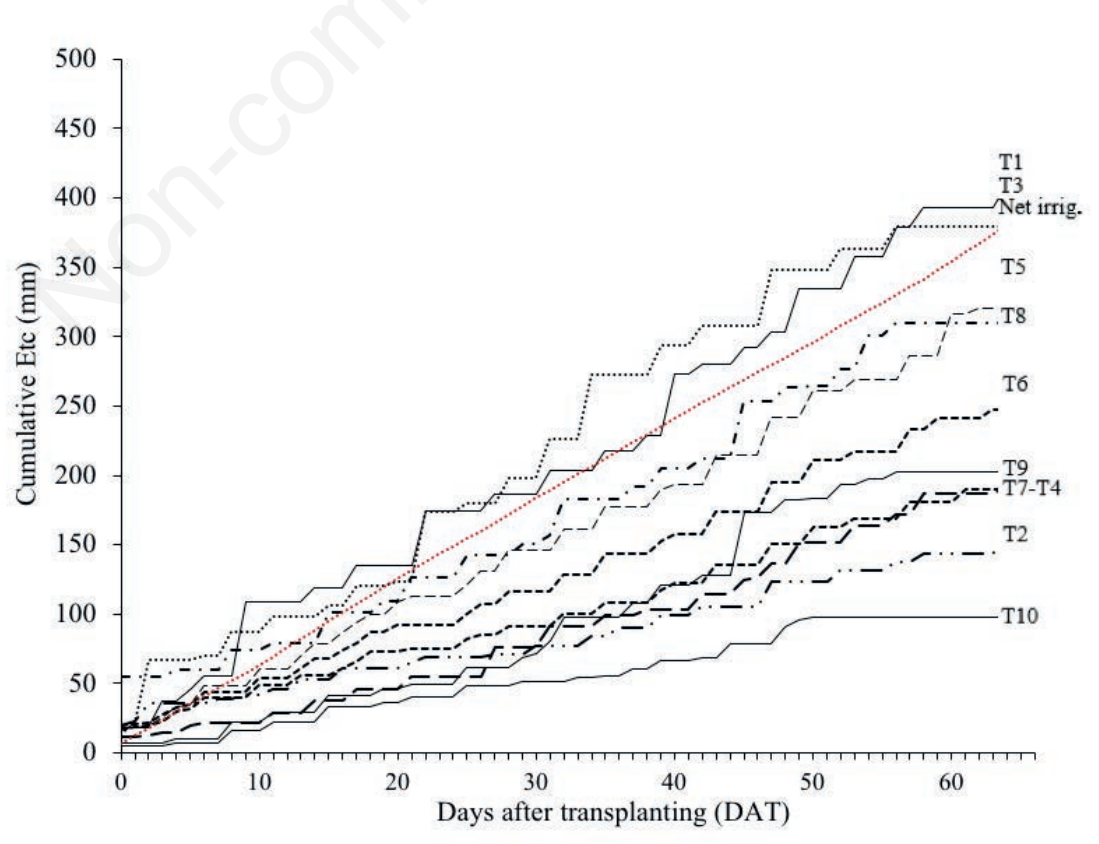

Figure 2. Observed cumulative crop evapotranspiration-Etc $(\mathrm{mm})$ under different irrigation regimes. $\mathrm{T}_{1}$ and $\mathrm{T}_{3}$ : full irrigation $(\mathrm{FI})$ $(100 \% E t c) ; T_{5}, T_{6}$ and $T_{8}:$ progressive deficit (PD) (70-90\% Etc); $\mathrm{T}_{4}, \mathrm{~T}_{7}$ and $\mathrm{T}_{9}:$ deficit irrigation $(\mathrm{DI})\left(50 \%\right.$ Etc); $\mathrm{T}_{2}$ and $\mathrm{T}_{10}:$ extreme deficit irrigation (EDI) $(<40 \%$ Etc) ; Net irrigation requirements. 
stress (from $40^{\circ} \mathrm{C}$ to $36^{\circ} \mathrm{C}$ ) on AquaCrop. These values were obtained from field observations and controlled climatic conditions made by Alvar-Beltrán et al. (2019a, 2020b), and where $36-38^{\circ} \mathrm{C}$ was identified as the critical threshold for quinoa polli- nation. The cv. Titicaca was not affected by low N-fertilisation under field conditions in Burkina Faso (Alvar-Beltrán et al., $2019 b$ ). For this reason, soil fertility was not a limiting factor and, therefore, not considered during the calibration process.

Table 3. Parameters used for the calibration of AquaCrop (Burkina Faso) and default values (Bolivia).

\begin{tabular}{llll} 
Climate & & Burkina Faso & Bolivia \\
Maximum temperature & & Daily data & - \\
Minimum temperature & ${ }^{\circ} \mathrm{C}$ & Daily data & - \\
\hline Crop evapotranspiration & ${ }^{\circ} \mathrm{C}$ & Daily data & Daily data \\
Precipitation & $\mathrm{mm} \mathrm{day}^{-1}$ & Daily data & Daily data \\
\hline Mean relative humidity & $\mathrm{mm} \mathrm{day}^{-1}$ & Daily data & -
\end{tabular}

\section{Development}

Plant density

Type of planting method

Transplanting

Recovered

Initial canopy cover

Canopy size seedling

Canopy expansion

Canopy decline

Max. canopy cover

Senescence

Maturity

Max. Canopy cover

Canopy decline

Flowering

Duration of the flowering

Length building up harvest index

Root deepening

Crop Production

Crop water productivity

Harvest index

Response to stresses

Canopy expansion

Stomatal closure

Early canopy senescence

Aeration stress

Salinity class

Air temperature stresses: pollination

\section{Management}

\section{Irrigation}

Method

Irrigation events

Field

Soil fertility

Mulches

Weed management

\section{Soil}

Texture

Permanent wilting point*

Field capacity*

Saturation*

Hydraulic conductivity*

Thickness

\section{Groundwater table}

Depth

Salinity

$\mathrm{dS} \mathrm{m}^{-1}$

$\begin{array}{ll}\text { USDA } & \text { Loamy-Sandy } \\ \% \mathrm{v} / \mathrm{v} & 14.8 \\ \% \mathrm{v} / \mathrm{v} & 25.9 \\ \% \mathrm{v} / \mathrm{v} & 47.1 \\ \mathrm{~mm} \text { day }^{-1} & 557 \\ \mathrm{~cm} & 120\end{array}$

Extremely tolerant to water stress

Moderately tolerant to water stress

Extremely tolerant to water stress

Sensitive to water logging

Moderately tolerant to salinity

Max (36) / Min (8)
200,000

Direct sowing

1.30

6.5

10.0

10.0

$73 / 1314$

$160 / 2880$

$180 / 3240$

75

28

$70 / 1260$

$20 / 360$

$90 / 1620$

100

10.5

50

As calibrated value As calibrated value As calibrated value As calibrated value As calibrated value $\operatorname{Max}(40)$ / Min (8)

DAT, days after transplanting; GDD, growing degree days; DAS, days after sowing. Default values for calibrating AquaCrop in the Bolivian Altiplano using genotypes Santa Maria and Real Blanca (Geerts et al., 2009; FAO, 2019). Crop default use DAS instead of DAT. *Soil values provided by Leu et al. (2010) for similar types of soil and same organic amendment. 


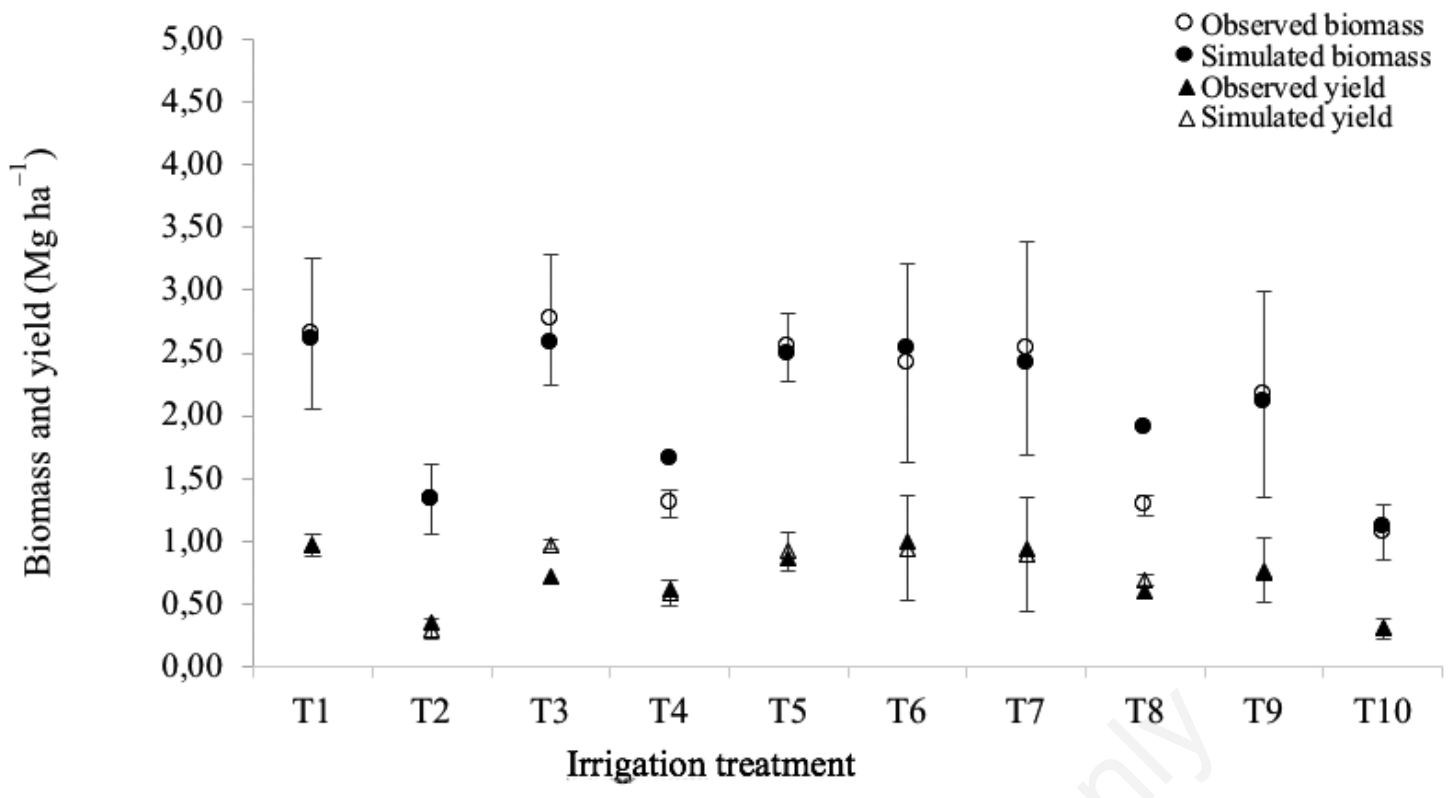

Figure 3. Observed biomass and yield values in the field and simulated biomass and yield using the AquaCrop model.

Table 4. Observed and simulated biomass and yield $\left(\mathrm{Mg} \mathrm{ha}^{-1}\right)$ for different irrigation regimes: full irrigation (FI), progressive drought (PD), deficit irrigation (DI) and extreme deficit irrigation (EDI).

\begin{tabular}{|c|c|c|c|c|c|c|c|c|c|c|}
\hline & \multicolumn{4}{|c|}{ Calibrated values } & \multicolumn{6}{|c|}{ Validated values } \\
\hline & $\begin{array}{c}\text { FI } \\
\left(T_{1}\right)\end{array}$ & $\begin{array}{l}\text { EDI } \\
\left(\mathrm{T}_{2}\right)\end{array}$ & $\begin{array}{c}\mathrm{FI} \\
\left(\mathrm{T}_{3}\right)\end{array}$ & $\begin{array}{c}\mathrm{DI} \\
\left(\mathrm{T}_{4}\right)\end{array}$ & $\begin{array}{l}\text { PD } \\
\left(T_{5}\right)\end{array}$ & $\begin{array}{c}\text { PD } \\
\left(\mathrm{T}_{6}\right)\end{array}$ & $\begin{array}{c}\mathrm{DI} \\
\left(\mathrm{T}_{7}\right)\end{array}$ & $\begin{array}{c}\text { PD } \\
\left(T_{8}\right)\end{array}$ & $\begin{array}{c}\text { DI } \\
\left(T_{9}\right)\end{array}$ & $\begin{array}{r}\text { EDI } \\
\left(T_{10}\right)\end{array}$ \\
\hline \multicolumn{11}{|l|}{ Crop outputs } \\
\hline Obs. biomass (Mg ha-1) & 2.655 & 1.338 & 2.765 & 1.300 & 2.545 & 2.420 & 2.540 & 1.285 & 2.174 & 1.071 \\
\hline Sim. biomass $\left(\mathrm{Mg} \mathrm{ha}^{-1}\right)$ & 2.605 & 1.329 & 2.575 & 1.654 & 2.495 & 2.541 & 2.425 & 1.910 & 2.118 & 1.122 \\
\hline Obs. biomass $\sigma\left(\mathrm{Mg} \mathrm{ha}^{-1}\right)$ & 1.195 & 0.555 & 1.041 & 0.218 & 0.534 & 1.597 & 1.693 & 0.173 & 1.642 & 0.427 \\
\hline Obs. yield (Mg ha-1) & 0.967 & 0.348 & 0.727 & 0.612 & 0.871 & 1.005 & 0.943 & 0.597 & 0.748 & 0.303 \\
\hline Sim. yield $\left(\mathrm{Mg} \mathrm{ha}^{-1}\right)$ & 0.966 & 0.301 & 0.976 & 0.589 & 0.921 & 0.941 & 0.893 & 0.687 & 0.771 & 0.304 \\
\hline Obs. yield $\sigma\left(\mathrm{Mg} \mathrm{ha}^{-1}\right)$ & 0.173 & 0.172 & 0.062 & 0.211 & 0.304 & 0.838 & 0.910 & 0.089 & 0.518 & 0.153 \\
\hline Obs. harvest index (\%) & 36 & 33 & 38 & 42 & 39 & 37 & 37 & 46 & 34 & 28 \\
\hline Sim. harvest index (\%) & 37 & 23 & 38 & 36 & 37 & 37 & 37 & 36 & 36 & 27 \\
\hline \multicolumn{11}{|l|}{ Avg. crop cycle stress* } \\
\hline Canopy expansion (\%) & 1 & 41 & 3 & 35 & 1 & 1 & 4 & 9 & 10 & 43 \\
\hline Stomatal closure (\%) & 1 & 37 & 3 & 31 & 2 & 1 & 4 & 14 & 7 & 52 \\
\hline
\end{tabular}

$\sigma$ corresponds to the standard deviation of observed biomass and yield values. *Average effect of water-stresses on canopy expansion and stomatal closure during the growing cycle

Table 5. Performance of AquaCrop calibration when comparing observed and simulated above-ground biomass $\left(\mathrm{Mg}^{-1}\right)$ and canopy cover $(\%)$.

\begin{tabular}{|c|c|c|c|c|}
\hline & \multicolumn{4}{|c|}{ Treatments } \\
\hline & $\mathrm{T} 1$ & $\mathrm{~T} 2$ & $\mathrm{~T} 3$ & $\mathrm{~T} 4$ \\
\hline \multicolumn{5}{|l|}{ Above-ground biomass } \\
\hline Pearson correlation coefficient (r) & $1.00 * * *$ & $0.99 * * *$ & $0.98 * *$ & $1.00^{* * *}$ \\
\hline Root mean square error-RMSE (Mg ha-1) & 0.200 & 0.200 & 0.300 & 0.200 \\
\hline Wilmott's index of agreement $(\mathrm{d})$ & 0.98 & 0.93 & 0.97 & 0.92 \\
\hline \multicolumn{5}{|l|}{ Canopy cover } \\
\hline Pearson correlation coefficient (r) & $0.99 * * *$ & $0.99 * * *$ & $0.98 * *$ & $0.94^{*}$ \\
\hline Root mean square error- RMSE (\%) & 5.3 & 11.6 & 4.7 & 7.5 \\
\hline Wilmott's index of agreement (d) & 0.96 & 0.67 & 0.96 & 0.87 \\
\hline
\end{tabular}

***Extremely significant $(\mathrm{P} \leq 0.001)$; **very significant $(\mathrm{P} \leq 0.01)$; ${ }^{*}$ significant $(\mathrm{P} \leq 0.05)$; ns: not significant $(\mathrm{P}>0.05)$. Very good $(\mathrm{d} \geq 0.9)$; good $(\mathrm{d} 0.8-0.9)$; moderate-good $(\mathrm{d} 0.65-0.79)$; moderate-good $(\mathrm{d} 0.50-0.64) ;$ poor (d 0.25-0.49); very poor ( $\mathrm{d} \leq 0.25)$. 


\section{Simulation of yield and biomass on AquaCrop}

The simulations of quinoa yields $\left(\mathrm{Mg} \mathrm{ha}^{-1}\right)$ and dry-aboveground biomass $\left(\mathrm{Mg} \mathrm{ha}^{-1}\right)$ by AquaCrop for the two-year experiment (2017-18 and 2018-19) were presented in Table 4 and Figure 3. For FI ( $T_{1}$ and $\left.T_{3}\right)$, the average simulated biomass and yields were $2.59 \mathrm{Mg} \mathrm{ha}^{-1}$ and $0.97 \mathrm{Mg} \mathrm{ha}^{-1}$, respectively; while for $\mathrm{PD}\left(\mathrm{T}_{5}, \mathrm{~T}_{6}\right.$ and $\left.\mathrm{T}_{8}\right)$, the average simulated biomass and yields were $2.32 \mathrm{Mg} \mathrm{ha}^{-1}$ and $0.85 \mathrm{Mg} \mathrm{ha}^{-1}$, respectively. However, there were no significant differences $(\mathrm{P}>0.05)$ when comparing the simulated values of both yield and biomass of PD versus FI. Furthermore, under DI $\left(\mathrm{T}_{4}, \mathrm{~T}_{7}\right.$ and $\left.\mathrm{T}_{9}\right)$, the average simulated biomass and yield were $2.07 \mathrm{Mg} \mathrm{ha}^{-1}$ and $0.75 \mathrm{Mg} \mathrm{ha}^{-1}$, respectively. While for EDI $\left(\mathrm{T}_{2}\right.$ and $\left.\mathrm{T}_{10}\right)$, the average simulated biomass and yield decreased to $1.23 \mathrm{Mg} \mathrm{ha}^{-1}$ and $0.30 \mathrm{Mg} \mathrm{ha}^{-1}$, respectively (Table 5). When comparing DI and EDI, significant differences $(\mathrm{P} \leq 0.05)$ were depicted in terms of both biomass and yield.

\section{Statistical analysis of yield, biomass and canopy cover}

For the calibration $\left(\mathrm{T}_{1}, \mathrm{~T}_{2}, \mathrm{~T}_{3}\right.$ and $\left.\mathrm{T}_{4}\right)$, different statistical indicators were used to test the degree of correlation between observed and simulated data (Table 5). For the aboveground biomass and canopy expansion, Pearson's correlation coefficient remained high in all treatments ( $\mathrm{r} 0.98$ and $\mathrm{P} \leq 0.01$ on average). However, relatively high RMSE values were observed, being the result of a high internal variability within treatments (between 0.2-0.3 $\mathrm{Mg} \mathrm{ha}^{-1}$ for biomass and 4.7-11.6\% for canopy cover). For the canopy cover, the largest RMSE differences were observed in $\mathrm{T}_{2}(11.6 \%)$, and to a lesser extent in $\mathrm{T}_{4}, \mathrm{~T}_{1}$ and $\mathrm{T}_{3}$ with values of $7.5,5.3$ and $4.7 \%$, respectively. The Wilmott's index of agreement (d) for biomass was corroborated with the Pearson's correlation coefficient, with d values between 0.92 and 0.98 . This implied very high agreement between predicted and observed readings. Nevertheless, both indices ( $d$ and $r$ ) strived to depict the internal variability within the treatments, whereas RMSE did not.

For the validation and calibration, a set of statistical indices (NRMSE, RMSE, MAPE and $\mathrm{R}^{2}$ ) were used to evaluate the performance of the AquaCrop model in terms of simulated grain yield and biomass (Table 6$)$. The calibrated $\left(\mathrm{T}_{1}-\mathrm{T}_{4}\right)$ and validated $\left(\mathrm{T}_{5}-\right.$ $\mathrm{T}_{10}$ ) NRMSE values were of $10.0 \%$ and $13.3 \%$ for biomass, and $19.2 \%$ and $7.3 \%$ for yield, respectively. In addition, a higher performance was observed when using the MAPE. The average calibrated and validated MAPE values were of $9.2 \%$ and $11.1 \%$ for biomass, and $12.9 \%$ and $6.0 \%$ for yield, respectively. Additionally,

Table 6. Performance of AquaCrop in biomass and yield simulation, average of all treatments.

\begin{tabular}{lcccc} 
& $\begin{array}{c}\text { RVSE } \\
\left(\mathrm{Mg} \mathrm{ha}^{-1}\right)\end{array}$ & $\begin{array}{c}\text { NRMSE } \\
(\%)\end{array}$ & $\begin{array}{c}\text { MAPE } \\
(\%)\end{array}$ & $\mathrm{r}^{2}$ \\
$\begin{array}{l}\text { Calibrated crop outputs } \\
\quad\end{array}$ & 0.298 & 11.4 & 9.2 & $0.94^{* *}$ \\
$\quad$ Biomass & 0.127 & 18.0 & 12.9 & $0.84^{*}$ \\
$\quad \begin{array}{l}\text { Yield } \\
\text { Validated crop outputs }\end{array}$ & & & & \\
$\quad$ Biomass & 0.301 & 14.8 & 11.1 & $0.84^{* *}$ \\
$\quad$ Yield & 0.639 & 9.2 & 6.0 & $0.95^{* * *}$ \\
\hline
\end{tabular}

RMSE, root mean square error; NRMSE, normalised-root-mean-square-error; MAPE, mean absolute percentage error; $\mathrm{R}^{2}$, coefficient of determination. ${ }^{* *}$ Extremely significant $(\mathrm{P} \leq 0.001) ;{ }^{* *}$ very significant $(\mathrm{P} \leq 0.01)$; * significant $(\mathrm{P} \leq 0.05)$; ns: not significant $(\mathrm{P}>0.05)$. ${ }^{\circ}$ Calibration values (average of $\mathrm{T}_{1}$ to $\mathrm{T}_{4}$ ) and validation values (average of $\mathrm{T}_{5}$ to $\mathrm{T}_{10}$ ).
$\mathrm{R}^{2}$ displayed a strong robustness between observed and simulated values both in the calibration $\left(\mathrm{T}_{1}-\mathrm{T}_{4}\right)$ and validation $\left(\mathrm{T}_{5}-\mathrm{T}_{10}\right)$, with $\mathrm{R}^{2}$ values of $0.94(\mathrm{P} \leq 0.01)$ and $0.84(\mathrm{P} \leq 0.01)$ for biomass, and of $0.84(\mathrm{P} \leq 0.05)$ and $0.95(\mathrm{P} \leq 0.001)$ for the yield, respectively.

\section{Discussion}

The first necessary step was to ascertain the validity of using the AquaCrop model for testing different irrigation regimes for growing quinoa in the Sahel. The main limitation of the model was that key calibrated parameters outputs, e.g. yield and biomass, were site-specific and therefore cannot be easily extrapolated elsewhere. Additionally, the model did not account for soil nutrient depletion, pest and diseases (e.g., mildew) affecting quinoa. However, during this research, neither pest nor diseases were reported because of such dry conditions.

The second step was to test the most suitable irrigation regimes for optimising water resources and obtaining the highest quinoa yields. High performance of the AquaCrop model was reflected in the similarities between observed and simulated values. This was shown to be valid for the calibration and validation of the biomass and grain yield in Burkina Faso. An adequate and satisfactory overall performance of the AquaCrop model was reported when modelling crop yield, biomass and canopy cover under different irrigation strategies with cotton (in Syria), Bambara groundnut (greenhouse in UK), soybean (in Nigeria) and maize (in Ethiopia) (Farahani et al., 2009; Karunaratne et al., 2011; Gebreselassie et al., 2015; Adeboye et al., 2017). Whilst the model was capable of producing accurate results for biomass and yield, it struggle, to some extent, to produce accurate estimations of the canopy expansion throughout the growing cycle. This was found during early vegetative stages and at leaf senescence, characterised by a very rapid expansion and decline of the canopy typically of environments with warm conditions and short photoperiods.

The concept of thermal time (or GDD) was used to analyse and compare heat units $\left({ }^{\circ} \mathrm{C}\right)$ with time units (days). The observed and simulated GDD values in AquaCrop $\left({ }^{\circ} \mathrm{C}\right)$ were (GDD for seedling and transplanting equal to $1851^{\circ} \mathrm{C}$ ) identical to those reported by Präger et al. (2018) in Germany for cv. Titicaca (GDD $1874^{\circ} \mathrm{C}$ ). Hence, the present study validated the GDD equation $\left(\mathrm{T}_{\text {base }}\right.$ equal to $3{ }^{\circ} \mathrm{C}$ for quinoa) elaborated by Jacobsen and Bach (1998) and used in AquaCrop. In addition, field experiments conducted in the Sahel, Middle East and North Africa (MENA) (Breidy, 2015; CNRADA, 2015; Djamal, 2015; Hassan, 2015; Saeed, 2015; Alvar-Beltrán et al., 2019b; Dao et al., 2020a) frequently reported the effect of heat stress on quinoa. The default values on AquaCrop for Bolivia showed that calibrated air temperature stress values in AquaCrop were too high $\left(40^{\circ} \mathrm{C}\right)$ for the genotype in study $(\mathrm{cv}$. Titicaca), hence having little impact on quinoa pollination (FAO, 2019). However, the present study demonstrated that heat stress adversely affected quinoa pollination, and for this reason calibrated default thresholds in AquaCrop were lowered down from $40^{\circ} \mathrm{C}$ to $36^{\circ} \mathrm{C}$ as reported by Alvar-Beltrán et al. (2020b) for cv. Titicaca. As acknowledged by Hatfield and Prueger (2015), heat stress and water deficits at flowering resulted in pollen dehydration and consequently lowering quinoa yields. The present study also showed that plants sown in December were more sensitive to heat stress conditions occurring at flowering than those sown in late October and along November. Preliminary results from the present study suggest the propensity for improving irrigation by using PD and DI types of irrigation schemes. Some of these research findings eluci- 
dated two important aspects regarding drip-irrigated quinoa. The first one was that under PD $\left(\mathrm{T}_{6}\right)$ and $\mathrm{DI}\left(\mathrm{T}_{7}\right)$ quinoa performed well in terms of yield (around 1.0 $\mathrm{Mg} \mathrm{ha}^{-1}$ ) when irrigated with small and frequent doses, 28 events from transplanting to maturity (10 weeks). As a result, PD and DI were considered optimal water strategies and could be employed during drought-stress conditions. PD and DI water saving irrigation strategies could be embraced and further promoted for drought-tolerant crops and be used as an adaptation measure under increasing rainfall variability in the Sahel region. The second important aspect was that yield losses between FI ( $\mathrm{T}_{1}$ and $\mathrm{T}_{3}$ with $0.97 \mathrm{Mg} \mathrm{ha}^{-1}$ and $415 \mathrm{~mm}$, averages of yield and water supply) and PD $\left(\mathrm{T}_{5}, \mathrm{~T}_{6}\right.$ and $\mathrm{T}_{8}$ with $0.85 \mathrm{Mg} \mathrm{ha}^{-1}$ and $307 \mathrm{~mm}$, averages of yield and water supply) were of $13 \%$, but with a water saving benefit of $25 \%$. The results of the present study were in harmony to those of Geerts et al. (2008) in the Bolivian Altiplano. The latter experiment concluded that quinoa yields could be stabilised through deficit irrigation strategies, reporting yields of 1.2 to $2.0 \mathrm{Mg} \mathrm{ha}^{-1}$ under DI.

\section{Conclusions}

This research demonstrates that quinoa is a drought tolerant crop with low water requirements, besides having extraordinary abilities to adapt to drought stress conditions as reported in EDI treatments. The simulations made in AquaCrop indicate that quinoa is also extremely tolerant to water stress in terms of canopy expansion and leaf senescence. The present study shows that irrigation scheduling and drip irrigation systems are crucial for water optimisation. Essentially, the objective for farmers is to save water whilst minimising yield losses to acceptable levels. If sown in early November under PD ( $\mathrm{T}_{6}$, with $263 \mathrm{~mm}$ water supply) and DI ( $\mathrm{T}_{7}$, with $198 \mathrm{~mm}$ water supply), quinoa can potentially perform well $\left(\approx 1.0 \mathrm{Mg} \mathrm{ha}^{-1}\right)$ under frequent irrigation, 28 times in the 10 weeks following transplantation. If water is not a limiting factor, farmers can apply FI less frequently $\left(\mathrm{T}_{1}\right.$ and $\mathrm{T}_{3}$, with $415 \mathrm{~mm}$ water supply) and attain higher yields. However, this option is not supported by this research because of increasing rainfall variability within the region.

If appropriate irrigation scheduling is followed (PD as opposed to FI), savings are incurred as follows: economic losses from fuel for water pumping, benefits alike from grain yields (13\% yield reduction from FI to $\mathrm{PD}$ ), and water preservation, very advantageous to farmers enabling them to save up to $25 \%$ of water between FI and PD strategies. The loamy-sandy soil texture typically of the Sahel, emphasised the need to invest more time irrigating but with lower amounts of water. However, farmers can accept yield reductions from PD, as the overall individual and community cost benefits from water preservation are considered as positive.

The present research highlights the need for a more extensive work on irrigation scheduling and on the production of improved modelling with crop and water productivity models, in order to give a real contribution on food security in Africa through water conservation strategies and highly nutritional crops. To that, other drought and heat tolerant crops grown in the Sahel region and having high nutritional properties, e.g., pearl millet and fonio, could be tested to better understand the effect of water-stress conditions and increasing temperatures on yield performance.

\section{References}

Adeboye OB, Schultz B, Adekalu KO, Prasad K, 2017. Modelling of response of the growth and yield of soybean to full and deficit irrigation by using Aquacrop. Irrig. Drain. 66:192-205.

Akumaga U, Tarhule A, Yusuf A, 2017. Validation and testing of the FAO AquaCrop model under different levels of nitrogen fertiliser on rainfed maize in Nigeria, West Africa. Agric. Forest Meteorol. 232:225-34.

Allen RG, Pereira LS, Raes D, Smith M, 1998. Crop evapotranspiration-Guidelines for computing crop water requirements-FAO Irrigation and drainage paper 56, 300(9), D05109. FAO, Rome, Italy.

Alvar-Beltrán J, Saturnin C, Dao A, Dalla Marta A, Sanou J, Orlandini S, 2019a. Effect of drought and nitrogen fertilisation on quinoa (Chenopodium quinoa Willd.) under field conditions in Burkina Faso. Ital. J. Agrometeorol. 1:33-43.

Alvar-Beltrán J, Dao A, Saturnin C, Dalla Marta A, Sanou J, Orlandini S, 2019b. Effect of drought, nitrogen fertilisation, temperature, and photoperiodicity on quinoa plant growth and development in the Sahel. Agron. J. 9:607.

Alvar-Beltrán J, Dao A, Dalla Marta A, Heureux A, Sanou J, Orlandini S, 2020a. Farmers' perceptions of climate change and agricultural adaptation in Burkina Faso. Atmosphere 11:827.

Alvar-Beltrán J, Verdi L, Dalla Marta A, Dao A, Vivoli R, Sanou J, Orlandini S, 2020b. The effect of heat stress on quinoa (cv. Titicaca) under controlled climatic conditions. J. Agric. Sci. 1-7.

Araya A, Habtu S, Hadgu KM, Kebede A, Dejene T, 2010. Test of AquaCrop model in simulating biomass and yield of water deficient and irrigated barley (Hordeum vulgare). Agric. Water Manage. 97:1838-46.

Araya A, Kisekka I, Holman J, 2016. Evaluating deficit irrigation management strategies for grain sorghum using AquaCrop. Irrig. Sci. 34:465-81.

Barbier B, Yacouba H, Karambiri H, Zoromé M, Somé B, 2009. Human vulnerability to climate variability in the Sahel: farmers' adaptation strategies in northern Burkina Faso. Environ. Manage. 43:790-803.

Biasutti M, Sobel AH, 2009. Delayed Sahel rainfall and global seasonal cycle in a warmer climate. Geophys. Res. Lett 36(23).

Breidy J, 2015. Final Report on quinoa Evaluation Trials in Lebanon. [Online-Report]. [Accessed on: $6^{\text {th }}$ May 2017]. Available from: http://quinoa.agrinnovation.net

Centre National de Recherche Agronomique et Development Agricole (CNRADA), 2015. Technical assistance for the introduction of Quinoa and appropriation/institutionalisation of its production in Mauritania. Project: (TCP/RAB/3403). FAO, Rome, Italy.

Dao A, Guira A, Alvar-Beltrán J, Gnanda A, Nebie L, Sanou J, 2020. Quinoa's response to different sowing periods in two agro-ecological zones of Burkina Faso. Ital. Agrometeorol. 63-72.

Darko RO, Shouqi Y, Haofang Y, Liu J, Abbey A. 2016. Calibration and validation of AquaCrop for deficit and full irrigation of tomato. Int. J. Agricult. Biol. Engine. 9:104-10.

de Fraiture C, Kouali GN, Sally H, Kabre P, 2014. Pirates or pioneers? Unplanned irrigation around small reservoirs in Burkina Faso. Agric. Water Manage. 131:212-20.

Djamal S, 2015. Technical assistance for the introduction of quinoa and appropriation/institutionalisation of its production in AlgeriaSecond Evaluation Report. [Online-Report]. [Accessed on: $6^{\text {th }}$ May 2017]. Available from: http://quinoa.agrinnovation.net 
Farahani HJ, Izzi G, Oweis TY, 2009. Parameterisation and evaluation of the AquaCrop model for full and deficit irrigated cotton. Agron. J. 101:469-76.

Food and Agriculture Organisation (FAO), 1990. Chapter 2: FAO Penman-Monteith equation. [Accessed on $8^{\text {th }}$ April 2019] Available from: http:/www.fao.org

Food and Agriculture Organisation (FAO), 2011. Aquastat database: Burkina Faso. [Accessed on $8^{\text {th }}$ April 2019] Available from: http://www.fao.org

Food and Agriculture Organisation (FAO), 2019. Land and Water, Databases and Software: Aquacrop [Accessed on 22 ${ }^{\text {nd }}$ April 2019] Available from: http://www.fao.org/aquacrop

Garcia M, Raes D, Jacobsen SE, 2003. Evapotranspiration analysis and irrigation requirements of quinoa (Chenopodium quinoa) in the Bolivian highlands. Agric. Water Manage. 60:119-34.

Gebreselassie Y, Ayana M, Tadele K, 2015. Field experimentationbased simulation of yield response of maize crop to deficit irrigation using AquaCrop model, Arba Minch, Ethiopia. Afr. J. Agric. Res. 10:269-80.

Geerts S, Raes D, Garcia M, Vacher J, Mamani R, Mendoza J, Taboada C, 2008. Introducing deficit irrigation to stabilise yields of quinoa (Chenopodium quinoa Willd.). Eur. J. Agron. 28:427-36.

Geerts S, Raes D, Garcia M, Miranda R, Cusicanqui JA, Taboada C, Mamani J, 2009. Simulating yield response of quinoa to water availability with AquaCrop. Agron. J. 101:499-508.

Geerts S, Raes D, Garcia M, 2010. Using AquaCrop to derive deficit irrigation schedules. Agric. Water Manage. 98:213-6.

Hargreaves GH, Samani ZA, 1985. Reference crop evapotranspiration from temperature. Appl. Engine. Agricult. 1:96-9.

Hassan L, 2015. Iraq final evaluation report on quinoa. [OnlineReport]. [Accessed on: 5th May 2017]. Available from: http://quinoa.agrinnovation.net

Hatfield JL, Prueger JH, 2015. Temperature extremes: Effect on plant growth and development. Weather Climate Extremes 10:4-10.

Ibrahim B, Karambiri H, Polcher J, Yacouba H, Ribstein P, 2014. Changes in rainfall regime over Burkina Faso under the climate change conditions simulated by 5 regional climate models. Climate Dynamics 42:1363-81.

Jacobsen SE, Bach AP, 1998. The influence of temperature on seed germination rate in quinoa (Chenopodium quinoa Willd. Seed Sci. Technol (Switzerland) 26:515-23.

Jacovides CP, Kontoyiannis H. 1995. Statistical procedures for the evaluation of evapotranspiration computing models. Agric. Water Manage. 27:365-71.

Karunaratne AS, Azam-Ali SN, Izzi G, Steduto P, 2011. Calibration and validation of FAO-AquaCrop model for irrigated and water deficient bambara groundnut. Exper. Agric. 47:509-27.

Kra E, 2014. FAO-56 Penman-Monteith daily from linear regression calibrated Hargreaves equation with wind terms in tropics with Limited data. Int. J. Agron. 2014; article ID 402809, 9 pages.

Leu JM, Traore S, Wang YM, Kan CE, 2010. The effect of organic matter amendment on soil water holding capacity change for irrigation water saving: Case study in Sahelian environment of Africa. Sci. Res. Essays 5:3564-71.

Mermoud A, Tamini TD, Yacouba H, 2005. Impacts of different irrigation schedules on the water balance components of an onion crop in a semi-arid zone. Agric. Water Manage. 77:282-95.

Mora C, Frazier AG, Longman RJ, Dacks RS, Walton MM, Tong EJ, Ambrosino CM, 2013. The projected timing of climate departure from recent variability. Nature 502:183.

Niang I, Ruppel OC, Abdrabo MA, Essel A, Lennard C, Padgham J, Urquhart P, 2014. Climate Change 2014: Impacts, Adaptation, and Vulnerability. Part B: Regional Aspects. Contribution of Working Group II to the Fifth Assessment Report of the Intergovernmental Panel on Climate Change [Barros, V.R., C.B. Field, D.J. Dokken, M.D. Mastrandrea, K.J. Mach, T.E. Bilir, M. Chatterjee, K.L. Ebi, Y.O. Estrada, R.C. Genova, B. Girma, E.S. Kissel, A.N. Levy, S. MacCracken, P.R. Mastrandrea, and L.L. White (eds.)]. Cambridge University Press, Cambridge, United Kingdom and New York, NY, USA, pp. 1199-1265.

Patrignani A, Ochsner TE, 2015. Canopeo: A powerful new tool for measuring fractional green canopy cover. Agron. J. 107:2312-20.

Präger A, Munz S, Nkebiwe PM, Mast B, Graeff-Hönninger S, 2018. Yield and quality characteristics of different quinoa (Chenopodium quinoa Willd.) Cultivars grown under field conditions in Southwestern Germany. Agronomy 8:197.

Raes D, Steduto P, Hsiao TC, Fereres E, 2009. AquaCrop-the FAO crop model to simulate yield response to water: II. Main algorithms and software description. Agron. J. 101:438-47.

Raes D, Steduto P, Hsiao TC, Fereres E, 2018a. Chapter 1: FAO cropwater productivity model to simulate yield response to water. Reference Manual. Food Agricultural Organisation (FAO), Rome, Italy.

Raes D, Steduto P, Hsiao TC, Fereres E, 2018b. Chapter 2 : Users guide. AquaCrop version 6.0-6.1. Reference Manual. Food Agricultural Organisation (FAO), Rome, Italy, pp. 2-302.

Razzaghi F, Plauborg F, Jacobsen SE, Jensen CR, Andersen MN, 2012. Effect of nitrogen and water availability of three soil types on yield, radiation use efficiency and evapotranspiration in fieldgrown quinoa. Agric. Water Manage. 109:20-9.

Saeed AL, 2015. Yemen Progress Report on quinoa. [Online-Report] [Accessed on: $6^{\text {th }}$ May 2017]. Available from: http://quinoa. agrinnovation.net

Sawadogo H, Bock L, Lacroix D, Zombré NP, 2008. Restauration des potentialités de sols dégradés à l'aide du zaï et du compost dans le Yatenga (Burkina Faso). Biotechnol. Agron. Soc. Environ. 12:279-90.

Sam-Amoah LK, Darko RO, Owusu-Sekyere JD, 2013. Calibration and validation of Aqua Crop for full and deficit irrigation of hot pepper. J. Agric. Biol. Sci. 8:175-8.

Steduto P, Hsiao TC, Raes D, Fereres E, 2009. AquaCrop - The FAO crop model to simulate yield response to water: I. Concepts and underlying principles. Agron. J. 101:426-37.

Steduto P, Hsiao TC, Fereres E, Raes D, 2012. Crop yield response to water (Vol. 1028). FAO, Rome, Italy.

Tabari H, Grismer ME, Trajkovic S, 2013. Comparative analysis of 31 reference evapotranspiration methods under humid conditions. Irrig. Sci. 31:107-17.

Wang YM, Traore S, Kerh T, 2009. Applying evapotranspiration reference model and rainfall contribution index for agricultural water management plan in Burkina Faso. Afr. J. Agricult. Res. 4:1493-504.

Willmott CJ, 1984. On the evaluation of model performance in physical geography. In: G.L. Gaile, C.J. Willmott (Eds.), Spatial Statistics and Models. D. Reidel, Boston, USA, pp 443-460.

Yabi I, Afouda F, 2012. Extreme rainfall years in Benin (West Africa). Quatern. Int. 262:39-43. 